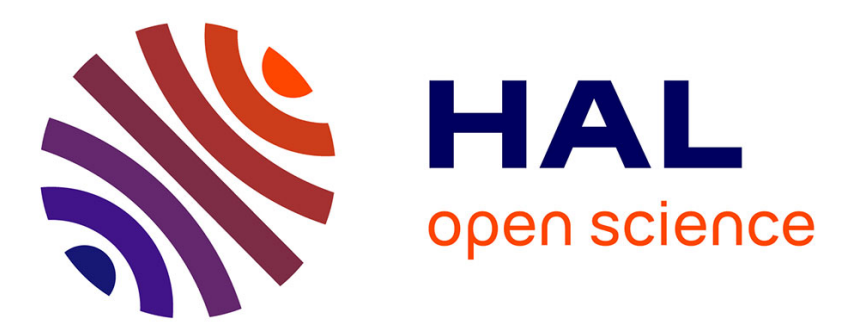

\title{
Reduction of [Cp*2Mo2O5] by thioglycolic acid in an aqueous medium: Synthesis and structure of $[\mathrm{Cp} * \mathrm{Mo}(\mu-\mathrm{SCH} 2 \mathrm{COO}) 2(\mu-\mathrm{S})]$
}

Funda Demirhan, Gülnur Taban, Miguel Baya, Chiara Dinoi, Jean-Claude Daran, Rinaldo Poli

\section{To cite this version:}

Funda Demirhan, Gülnur Taban, Miguel Baya, Chiara Dinoi, Jean-Claude Daran, et al.. Reduction of [Cp*2Mo2O5] by thioglycolic acid in an aqueous medium: Synthesis and structure of $[\mathrm{Cp} * \mathrm{Mo}(\mu-\mathrm{SCH} 2 \mathrm{COO}) 2(\mu-\mathrm{S})]$. Journal of Organometallic Chemistry, 2006, 691 (4), pp.648-654. 10.1016/j.jorganchem.2005.10.006 . hal-03196152

\section{HAL Id: hal-03196152 https://hal.science/hal-03196152}

Submitted on 12 Apr 2021

HAL is a multi-disciplinary open access archive for the deposit and dissemination of scientific research documents, whether they are published or not. The documents may come from teaching and research institutions in France or abroad, or from public or private research centers.
L'archive ouverte pluridisciplinaire HAL, est destinée au dépôt et à la diffusion de documents scientifiques de niveau recherche, publiés ou non, émanant des établissements d'enseignement et de recherche français ou étrangers, des laboratoires publics ou privés. 


\section{Reduction of $\left[\mathrm{Cp}_{2}{ }_{2} \mathrm{Mo}_{2} \mathrm{O}_{5}\right]$ by thioglycolic acid in an aqueous medium. Synthesis and structure of $\left[\left\{\mathrm{Cp} * \mathrm{Mo}\left(\mu-\mathrm{SCH}_{2} \mathrm{COO}\right)\right\}_{2}(\mu-\mathrm{S})\right]$.}

Funda Demirhan*, ${ }^{\mathrm{a}}$ Gülnur Tabana, Miguel Baya, ${ }^{\mathrm{b}}$ Chiara Dinoi, ${ }^{\mathrm{b}}$ Jean-Claude Daran ${ }^{\mathrm{b}}$ and Rinaldo Poli*b

${ }^{a}$ Celal Bayar University, Faculty of Sciences \& Liberal Arts, Department of Chemistry, 45030, Muradiye-Manisa, Turkey

${ }^{\mathrm{b}}$ Laboratoire de Chimie de Coordination, UPR CNRS 8241, 205 Route de Narbonne, 31077

Toulouse Cedex, France

Proofs to: Prof. Rinaldo Poli

Tel +33561333195

Fax +33561553003

E-mail: poli@lcc-toulouse.fr

Keywords: Molybdenum, aqueous organometallic chemistry, alkylsulfido ligands, carboxilato ligands, C-S bond activation. 


\begin{abstract}
Compound $\left[\mathrm{Cp}^{*}{ }_{2} \mathrm{Mo}_{2} \mathrm{O}_{5}\right]$ reacts with thioglycolic acid, $\mathrm{HSCH}_{2} \mathrm{COOH}$, in an acidic $\left(\mathrm{CF}_{3} \mathrm{COOH}\right)$ mixed water-methanol solvent, to yield compound $\left[\left\{\mathrm{Cp} * \mathrm{Mo}\left(\mu-\mathrm{SCH}_{2} \mathrm{CO}_{2}\right)\right\}_{2}(\mu-\right.$ S)]. During this reaction, the thioglycolic acid acts as a reducing agent, as a ligand, and provides a sulfide ion for the Mo-S-Mo bridge. The molecular structure of the product can be described as containing two four-legged piano stools that share three legs. The Mo-Mo distance of 2.792(7) $\AA$ indicates metal-metal bonding, in agreement with the compound diamagnetism.
\end{abstract}




\section{Introduction}

Aqueous organometallic chemistry is attracting growing interest because of its "green" impact [1-3] and because of its potential in catalytic [4, 5] and biomedical applications [6]. Its development, however, has mostly been restricted to low-valent systems to which hydrophilic functionalities are added on the ligand periphery [7-9], in order to make the systems compatible with an aqueous environment. Whereas high oxidation organometallics, mostly supported by oxo ligands, are now a well established family of compounds $[10,11]$, their systematic investigation in water has received little attention. Nevertheless, the metal bonded oxo functionality is related, through protonation equilibria, to hydroxo and aqua ligands, leading to the potential of aqueous solubility and to the generation of open coordination sites for substrate activation and catalysis. In addition, the greater metal electronegativity in the higher oxidation states confers a higher degree of covalency to the metal carbon bonds with odd-electron carbon ligands (i.e. alkyls, allyls, cyclopentadienyls, etc.), which consequently may become quite resistant toward hydrolytic decomposition. For a redox-active metal, reduction of a high oxidation state oxo complex should favour the generation of aqua ligands, opening the way to catalytic and electrocatalytic applications [12].

We have recently initiated a research program aimed at exploiting the chemistry of high oxidation state organometallic compounds in water and have focused our attention on the speciation [13] and electrochemical behaviour $[14,15]$ of compound $\left[\mathrm{Cp}^{*}{ }_{2} \mathrm{Mo}_{2} \mathrm{O}_{5}\right]$. The Cp*-Mo bond is quite hydrolytically stable, being split only quite slowly at very low pH [16]. By chemical reduction with zinc in an acidic aqueous medium, novel oxo-supported 
complexes of $\mathrm{Cp}^{*} \mathrm{Mo}^{\mathrm{V}}$ and $\mathrm{Cp}^{*} \mathrm{Mo}^{\mathrm{IV}}$ have been obtained, the vacant positions left over by the removal of water ligands (from the expected protonation of oxo ligands) being filled by the anions of the acids used (acetic, trifluoroacetic) [17, 18].

In this contribution, we report the reactivity of $\left[\mathrm{Cp}^{*}{ }_{2} \mathrm{Mo}_{2} \mathrm{O}_{5}\right]$ with a thiol-containing organic acid, the thioglycolic acid, $\mathrm{HSCH}_{2} \mathrm{COOH}$. This reaction is interesting in comparison with the well-studied reduction of $\mathrm{MoO}_{4}{ }^{2-}$ by the same reagent, of interest in bioinorganic chemistry as a model for the action of cysteine in molybdenum hydroxylase enzymes.[19-23] It will be shown that the substrate is capable to reduce the starting complex, leading to a thioglycolate complex of $\mathrm{Cp}^{*} \mathrm{Mo}^{\mathrm{IV}}$. The abstraction of a sulfide ion also takes place during this transformation.

\section{Experimental Section}

\subsection{General Methods}

All preparations and manipulations were carried out with Schlenk techniques under an oxygen-free argon atmosphere. All glassware was oven-dried at $120^{\circ} \mathrm{C}$. Solvents were dried by standard procedures and distilled under dinitrogen prior to use. ${ }^{1} \mathrm{H}$ NMR spectra were recorded on a Bruker AC200, operating at $200 \mathrm{MHz}$. Chemical shifts are expressed in ppm downfield from $\mathrm{Me}_{4} \mathrm{Si}$. Coupling constants are given in Hertz. Mass spectra were recorded with a NERMAG R10-10 instrument. The starting compound, [Cp* $\left.{ }_{2} \mathrm{Mo}_{2} \mathrm{O}_{5}\right]$, was prepared as described in the literature [24]. The thioglycolic acid (98\%, Fluka) was used as received. An ${ }^{1} \mathrm{H}$ NMR investigation of this material in $\mathrm{CDCl}_{3}$ revealed that it is contaminated by the 
corresponding methyl ester (methyl mercaptoacetate), $\mathrm{HSCH}_{2} \mathrm{COOCH}_{3}$ (7.7\% by integration of the resonances), by comparison with an authentic sample.

\subsection{Preparation of $\left[\mathrm{Cp} * \mathrm{Mo}\left(\mu-\mathrm{SCH}_{2} \mathrm{COO}\right)\right]_{2}(\mu-\mathrm{S})$}

$\mathrm{HSCH}_{2} \mathrm{COOH}(0.25 \mathrm{~g}, 2.7 \mathrm{mmol})$ and 9 drops of $\mathrm{CF}_{3} \mathrm{COOH}$ were added to a solution of $\left[\left(\mathrm{Cp} * \mathrm{MoO}_{2}\right)_{2} \mathrm{O}\right](0.15 \mathrm{~g}, 0.27 \mathrm{mmol})$ in $\mathrm{MeOH}: \mathrm{H}_{2} \mathrm{O}(1: 1,5 \mathrm{~mL})$. The mixture was stirred under argon at room temperature for $3 \mathrm{~h}$ during which time a precipitate formed and the color changed from yellow, through dark yellow and brown, to finally yield a red suspension. All solvents were removed in vacuo. The residue was extracted with THF, followed by addition of pentane to yield a red precipitate, which was further recrystallized from $\mathrm{THF} / \mathrm{Et}_{2} \mathrm{O}(47 \mathrm{mg}$, $26 \%$ yield). The product is soluble in $\mathrm{CH}_{2} \mathrm{Cl}_{2}$ and $\mathrm{THF}$, insoluble in $\mathrm{Et}_{2} \mathrm{O}$ and saturated hydrocarbons. The NMR spectrum of the isolated product showed only the presence of the title compound, but the presence of a paramagnetic compound, which could not be crystallized in pure form, was revealed by EPR spectroscopy in $\mathrm{CDCl}_{3}\left(\mathrm{~g}=1.991\right.$, a $\mathrm{Mo}_{\mathrm{o}}=35.2$ G). Purification was attempted by chromatography through a silica gel column (ca. $1 \mathrm{~cm}$ diameter $\mathrm{x} 10 \mathrm{~cm})$, using pentane/ $\mathrm{MeOH}(7: 3)$ as eluent. The title product was recovered as a red powder from a first, major red fraction, after evaporation to dryness. However, this was still contaminated by the EPR-active by-product. In addition, the compound is slowly decomposed by contact with the silica support.

A single crystal for the X-ray analysis was obtained by diffusion of a pentane layer into a red $\mathrm{CH}_{2} \mathrm{Cl}_{2}$ solution of the crude reaction product at room temperature. ${ }^{1} \mathrm{H} \mathrm{NMR}\left(\mathrm{CDCl}_{3}\right)$ :

$2.09 \mathrm{ppm}\left(\mathrm{s}, 15 \mathrm{H}, \mathrm{Cp}^{*}\right), 2.94\left(\mathrm{AB}\right.$ system, $4 \mathrm{H}, \mathrm{SCH}_{2} \mathrm{CO}_{2}, \Delta v=56.0 \mathrm{~Hz} ;{ }^{2} \mathrm{~J}_{\mathrm{HH}}=16.0 \mathrm{~Hz}$ ). 
MS $\left(\mathrm{CI} / \mathrm{NH}_{3}\right): \mathrm{m} / \mathrm{z} 692\left(\mathrm{M}+\mathrm{NH}_{4}{ }^{+}, 23\right), 674\left(\mathrm{MH}^{+}, 100\right), 659\left(\mathrm{MH}^{+}-\mathrm{O}, 5.5\right), 617\left(\mathrm{MH}^{+}-\right.$ $\left.\mathrm{CH}_{2} \mathrm{CO}_{2}, 5.5\right), 591\left(\mathrm{MH}^{+}-\mathrm{CH}_{2} \mathrm{CO}_{2}-\mathrm{CH}_{2} \mathrm{C}, 7.5\right), 575\left(\mathrm{MH}^{+}-\mathrm{CH}_{2} \mathrm{CO}_{2}-\mathrm{CH}_{2} \mathrm{CO}, 22\right), 559\left(\mathrm{MH}^{+}-\right.$ $\left.2 \mathrm{CH}_{2} \mathrm{CO}_{2}, 18\right)$.

In a separate experiment, the reaction mixture was evaporated to dryness and the residue was washed with pentane. The extract was evaporated and the residue was dried and dissolved in DMSO- $d_{6}$. This solution exhibited an NMR spectrum with a major peak at $\delta$ 3.65, close to the position reported for the disulfide compound $\mathrm{HOOCCH}_{2} \mathrm{SSCH}_{2} \mathrm{COOH}$ (3.63) [25], and mass values in the EI MS (70 eV) at $\mathrm{m} / z 137$ (M-COOH, 2.9\%), 123 (M$\left.\mathrm{CH}_{2} \mathrm{COOH}, 2.4 \%\right), 119\left(\mathrm{M}-\mathrm{COOH}-\mathrm{H}_{2} \mathrm{O}, 7.9 \%\right)$, which are also reported for the same molecule [25].

\section{3. $X$-ray analysis}

Single crystal was mounted under inert perfluoropolyether at the tip of glass fibre and cooled in the cryostream of the Oxford-Diffraction XCALIBUR CCD diffractometer.

The structures was solved by direct methods (SIR97) [26] and refined by least-squares procedures on $\mathrm{F}^{2}$ using SHELXL-97 [27]. All $\mathrm{H}$ atoms attached to carbon were introduced in calculation in idealised positions and treated as riding models. The drawing of the molecules was realised with the help of ORTEP32 [28]. The statistically distributed disulfide and dichloromethane molecules were freely refined. The crystal data and refinement parameters are shown in Table 1 and selected geometric parameters are collected in Table 2. 
$<$ Table 1 and Table 2>

Crystallographic data (excluding structure factors) have been deposited with the Cambridge Crystallographic Data Centre as supplementary publication no. CCDC 283407. Copies of the data can be obtained free of charge on application to the Director, CCDC, 12 Union Road, Cambridge CB2 1EZ, UK (fax: (+44) 1223-336-033; e-mail: deposit@ccdc.cam.ac.uk).

\section{Results and Discussion}

The title compound is produced by the direct interaction, without any reducing agent, of thioglycolic acid, $\mathrm{HSCH}_{2} \mathrm{COOH}$, with $\left[\mathrm{Cp}_{2}{ }_{2} \mathrm{Mo}_{2} \mathrm{O}_{5}\right]$, in an strongly acidic $\left(\mathrm{CF}_{3} \mathrm{COOH}\right)$ mixed $\mathrm{MeOH} /$ water solvent. As confirmed by the X-ray structure (vide infra), the product is a dinuclear complex in which the two metal atoms have the formal oxidation state IV. Therefore, a first role of the thioglycolic acid is as a reducing agent, taking the metal oxidation state from VI to IV. It is well known that thiols can act as one-electron reducing agents, being in turn oxidized to disulfide derivatives. The presence of compound HOOC-

$\mathrm{CH}_{2}-\mathrm{S}-\mathrm{S}-\mathrm{CH}_{2}-\mathrm{COOH}$ in solution has been confirmed by ${ }^{1} \mathrm{H}$ NMR and mass spectrometry of the reaction mixture before separation and crystallization of the metal product. In addition, the S-S coupling product is trapped as an interstitial molecule in the crystal structure of the product (vide infra), thus unambiguously proving the reducing action of the sulfur reagent. The isolated product contains one doubly deprotonated thioglycolic acid molecule as a ligand 
per each Mo atom. Thus, a second role of the thioglycolic acid is as a ligand, transferring its protons to the oxo ligands, with the elimination of water. Finally, the product contains a bridging sulfido ligand, which must necessarily derive from the thioglycolic acid reagent through a process of $\mathrm{C}-\mathrm{S}$ bond cleavage.

It is interesting to remark that, contrary to the reaction reported here, no sulfur extraction from thioglycolic acid has been documented for the related reaction of the same thiol reagent with $\mathrm{MoO}_{4}{ }^{2-} \cdot[19-23]$ The various products that have been isolated and characterized from that reaction only contain the doubly deprotonated thioglycolic acid as a ligand and terminal or bridging oxo ligands: $\left[\left\{\mathrm{Mo}^{\mathrm{V}} \mathrm{O}\left(\mathrm{SCH}_{2} \mathrm{CO}_{2}\right)_{2}\right\}_{2}(\mu-\mathrm{O})\right]^{4-}[22]$, $\left[\left\{\mathrm{Mo}^{\mathrm{V}} \mathrm{O}\left(\mathrm{SCH}_{2} \mathrm{CO}_{2}\right)\right\}_{2}(\mu-\mathrm{O})\left(\mu-\mathrm{SCH}_{2} \mathrm{CO}_{2}\right)\right]^{2-}[22]$, and $\left[\left\{\mathrm{Mo}^{\mathrm{V}} \mathrm{O}\left(\mathrm{SCH}_{2} \mathrm{CO}_{2}\right)\right\}\left(\mu-\mathrm{SCH}_{2} \mathrm{CO}_{2}\right)_{2}\right]^{2-}$ $[21,23]$. Other mononuclear, EPR active intermediates have also been detected, but not isolated. In addition, a more reduced, air stable $\mathrm{Mo}^{\mathrm{IV}}$ product has been isolated but, to the best of our knowledge, its structure remains unknown.[20] All those products, like the compound reported here, were obtained working in aqueous media with commercially available thioglycolic acid (without further purification). The reagent used does not contain any $\mathrm{H}_{2} \mathrm{~S}$ impurity $\left(\mathrm{Ag}(\mathrm{CN})_{2}{ }^{-}\right.$test).[29] On the other hand, a ${ }^{1} \mathrm{H}$ NMR investigation indicates that it is contaminated by a small amount (ca. 8\%) of its methyl ester, $\mathrm{HSCH}_{2} \mathrm{COOMe}$. This compound should in principle react similarly to the acid with respect to the sulfide abstraction process, thus the outcome of the reaction does not appear to be attributable to the presence of impurities in the reagent. It seems, therefore, that the sulfide extraction process is more favorable when using the organometallic reagent $\mathrm{Cp}_{2}{ }_{2} \mathrm{Mo}_{2} \mathrm{O}_{5}$, relative to the inorganic molybdate. 
In previous mechanistic studies, it was established that the first step of the of the $\mathrm{MoO}_{4}{ }^{2-}$ reaction is formation of the mononuclear $\left[\mathrm{Mo}^{\mathrm{VI}} \mathrm{O}_{2}\left(\mathrm{SCH}_{2} \mathrm{CO}_{2}\right)_{2}\right]^{2-}$ complex, which is subsequently reduced by the excess thioglycolic acid to produce mononuclear species, followed by dimerization. A similar process may well occur here. It is interesting to remark that an EPR active species (presumably monomeric) is also formed during the $\mathrm{Cp}^{*}{ }_{2} \mathrm{Mo}_{2} \mathrm{O}_{5}$ reduction, see Experimental part. Our efforts to separate this species from the dinuclear $\mathrm{Mo}^{\mathrm{IV}}$ product, however, were unsuccessful. It is not clear at what point and by what precise mechanism the sulfur atom is abstracted during the formation of the title compound. The formation of $\mathrm{H}_{2} \mathrm{~S}$ from the thioglycolic acid reagent by exchange with the water solvent appears unlikely, since this reaction is not described in the literature. Rather, it is well known that $\mathrm{C}-\mathrm{O}$ bonds exchange with functions containing the $\mathrm{S}-\mathrm{H}$ bonds to yield products containing C-S and O-H bonds, even under strongly acidic conditions like those used in our reaction.[30] It is possible, however, that the sulfide abstraction is favored by the greater affinity of Mo for $\mathrm{S}$ vs. $\mathrm{O}$ in the $+\mathrm{IV}$ oxidation state. Indeed, the presence of the $\mathrm{Cp}^{*}$ ligand could render the Mo acidic center softer, therefore having a greater relative affinity for $\mathrm{S}$ vs. $\mathrm{O}$, and more susceptible to reduction.

It is also possible to conceive an alternative pathway: after coordination of the sulfur donor, the S-C bond could be reductively cleaved (the electrons being provided by the Mo center or by additional thioglycolic acid equivalents) under the influence of the Mo affinity for S. Other C-S bond breaking reactions on dinuclear cyclopentadienylmolybdenum complexes have been reported [31-36]. In this respect, the reaction would mimic the hydrodesulfurization process, which is in fact typically catalyzed by molybdenum-sulfur 
compounds [37, 38]. Among the various sulfur-containing substrates that have been used for model studies [39, 40], simple thiols are the easiest to desulfurize [41] and the assistance of the carboxylic function in thioglycolic acid may render such a process particularly favorable.

The NMR spectrum of the isolated product is fully consistent with the solid state molecular structure, since it shows an $\mathrm{AB}$ patters for the diastereotopic methylene protons of the $\mathrm{SCH}_{2} \mathrm{CO}_{2}$ ligands, and a single $\mathrm{Cp}^{*}$ resonance, in a 1:1:15 ratio. The mass spectrum (chemical ionization with $\mathrm{NH}_{3}$ ) shows the molecular ion plus a captured proton as the most intense isotopic envelope (see Figure 1), the second most intense one being 17 mass units higher and corresponding to the molecular ion plus a captured ammonium cation.
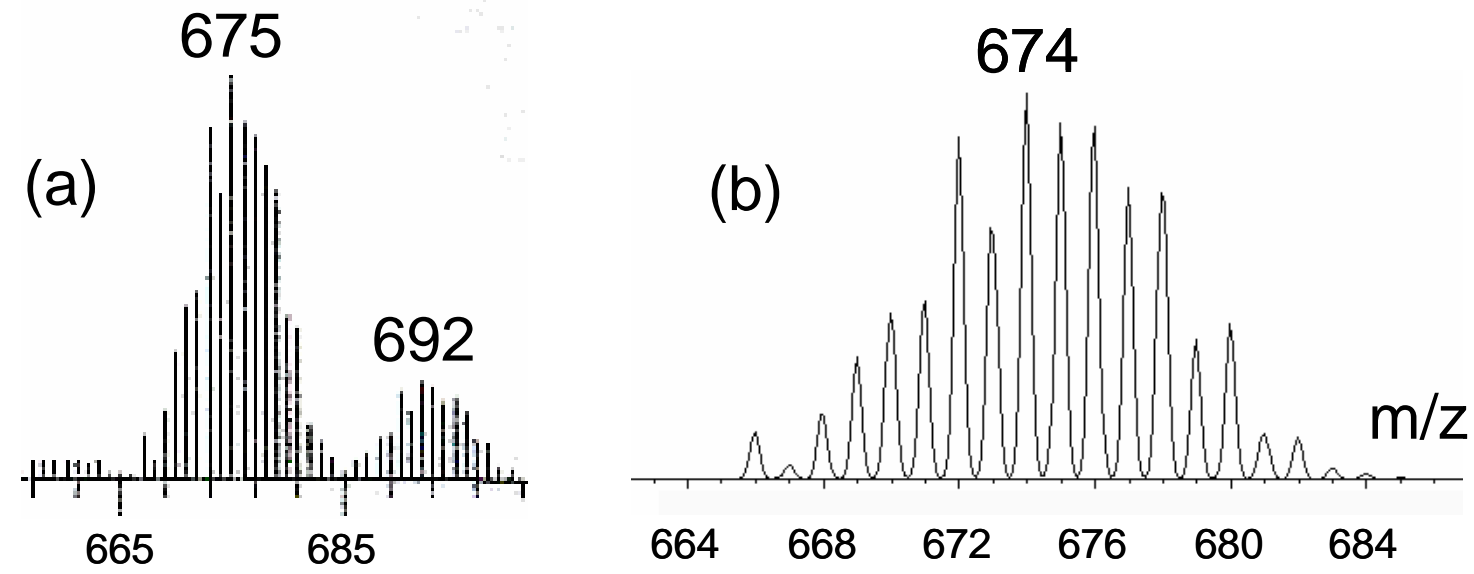

Figure 1. Mass spectrum $\left(\mathrm{Cl} / \mathrm{NH}_{3}\right)$ of compound $\left[\mathrm{Cp} * \mathrm{Mo}\left(\mu-\mathrm{SCH}_{2} \mathrm{COO}\right)\right]_{2}(\mu-\mathrm{S})$. (a) Experimental. (b) Simulated for $\mathrm{C}_{24} \mathrm{H}_{34} \mathrm{Mo}_{2} \mathrm{O}_{4} \mathrm{~S}_{3}$.

The molecular structure, as determined by single crystal X-ray diffraction, is shown in Figure 2. The geometry can be described as the fusion of two 4-legged piano stools through 
the sharing of three legs, which correspond to the S1, S2 and S3 donor atoms. The fourth leg for each metal is the oxygen atom of the thioglycolate unit (O11 for Mo1 and O21 for Mo2). Thus, each glycolate ligand acts as 6 electron donor, two electrons through the terminally bonded carboxylate function and four electron through the bridging sulfido function. There seems to be only two precedents of such triply bridged framework for two 4-legged piano stools of $\mathrm{Mo}^{\mathrm{IV}}$, namely $\left[\mathrm{Cp}^{*}{ }_{2} \mathrm{Mo}_{2}(\mu-\mathrm{O})(\mu-\mathrm{Cl})_{2} \mathrm{Cl}_{2}\right][42]$ and $\left[\mathrm{Cp}^{*}{ }_{2} \mathrm{Mo}_{2}\left(\mu-\mathrm{Cl}_{3} \mathrm{Cl}_{2}\right]^{+}\right.$[43]. Other examples, however, are known for $\mathrm{Mo}^{\mathrm{III}}$, e.g. $\left[\mathrm{Cp}_{2} \mathrm{Mo}_{2}(\mu-\mathrm{SMe})_{3}(\mathrm{CO})_{2}\right]^{+}[36]$ and $\left[\mathrm{Cp}_{2} \mathrm{Mo}_{2}(\mu-\mathrm{SMe})_{2}(\mu-\mathrm{SH})(\mathrm{CO})_{2}\right]^{+}[44]$. The most interesting metric parameter (see Table 2) is the metal-metal distance $[2.792(7) \AA]$, which is rather close to those of the above mentioned dinuclear $\mathrm{Mo}^{\mathrm{IV}}$ compounds with analogous structure $\left[2.720(8) \AA\right.$ in $\left[\mathrm{Cp}^{*}{ }_{2} \mathrm{Mo}_{2}(\mu-\right.$ O) $\left.\left(\mu-\mathrm{Cl}_{2}\right)_{2} \mathrm{Cl}_{2}\right][42]$ and 2.866(2) $\AA$ in $\left[\mathrm{Cp}^{*}{ }_{2} \mathrm{Mo}_{2}\left(\mu-\mathrm{Cl}_{3} \mathrm{Cl}_{2}\right]^{+}\right]$[43]. The metal-metal distance is also quite similar for the related $\mathrm{Mo}^{\mathrm{III}}$ dinuclear complexes $\left\{2.785(2) \AA\right.$ in $\left[\mathrm{Cp}_{2} \mathrm{Mo}_{2}(\mu-\right.$ $\left.\mathrm{SMe})_{3}(\mathrm{CO})_{2}{ }^{+}\right][36]$ and $2.772(2) \AA$ in $\left.\left[\mathrm{Cp}_{2} \mathrm{Mo}_{2}(\mu-\mathrm{SMe})_{2}(\mu-\mathrm{SH})(\mathrm{CO})_{2}\right]^{+}[44]\right\}$. This is expected, since the two electrons that make the difference between the electronic structures of $\mathrm{Mo}^{\mathrm{III}}$ and $\mathrm{Mo}^{\mathrm{IV}}$ triply-bridged (CpMo)2-type compounds are located in essentially nonbonding orbitals [43]. The Mo-S distances to the bridging sulfido ligand are shorter [average 2.310(4) $\AA$ ], as expected, than those to the $\mathrm{S}$ atom of the thioglycolato ligand [average 2.452(17) $\mathrm{A}$ ]. 


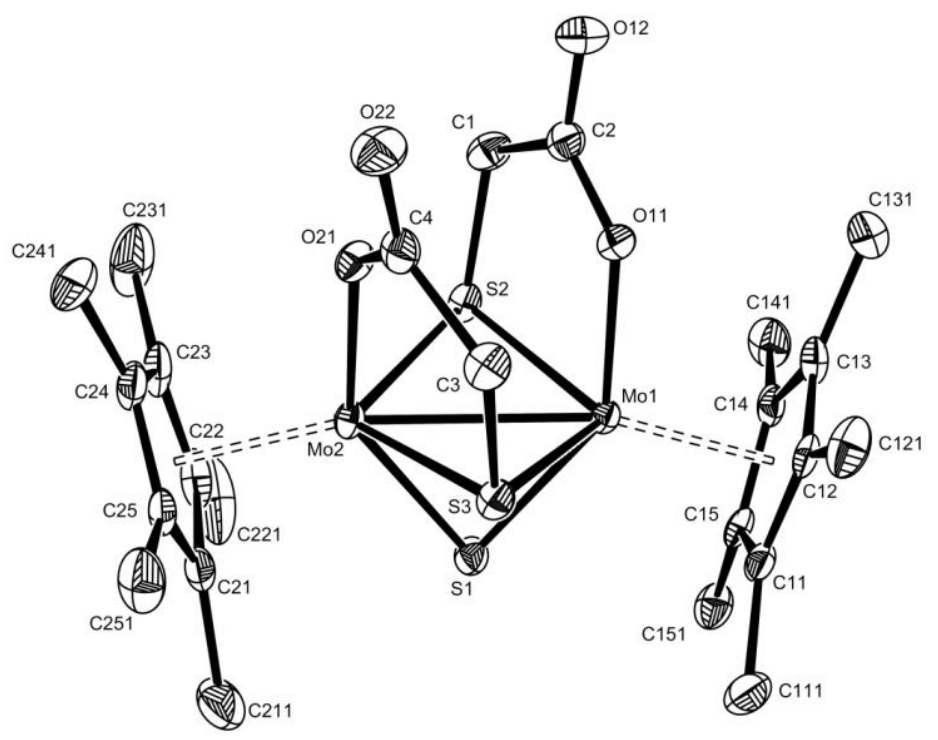

Figure 2. An ORTEP view of the $\left[\mathrm{Cp} * \mathrm{Mo}\left(\mu-\mathrm{SCH}_{2} \mathrm{COO}\right)\right]_{2}(\mu-\mathrm{S})$ molecule. The ellipsoids are drawn at the $40 \%$ probability level and the $\mathrm{H}$ atoms are omitted for clarity.

As mentioned above, the crystal structure contains the S-S coupling product resulting from the oxidation of the thioglycolic acid, $\mathrm{HOOCCH}_{2} \mathrm{~S}-\mathrm{SCH}_{2} \mathrm{COOH}$. The molecule is located at half occupancy near the $[1,1 / 2,0]$ inversion center, a half occupancy dichloromethane molecule also sharing the same site (see Figure 3). Obviously, when the disulfide is located on one side of the symmetry element, the dichloromethane occupies the space on the opposite side, and viceversa. Another full occupancy dichloromethane is also present in another general position, resulting in the overall crystal formulation as $\left[\mathrm{Cp}_{2}{ }_{2} \mathrm{Mo}_{2}\left(\mu-\mathrm{SCH}_{2} \mathrm{COO}\right)_{2}(\mu-\mathrm{S})\right] \cdot 1.5\left(\mathrm{CH}_{2} \mathrm{Cl}_{2}\right) \cdot 0.5\left(\mathrm{HOOCCH}_{2} \mathrm{SSCH}_{2} \mathrm{COOH}\right)$. All atoms of the two half-occupancy interstitial molecules are well-behaved in the refinement of the intensity data, and the precisely determined S-S distance of 2.026(4) A compares rather well 
with typical distances in crystallographically determined RS-SR molecules, e.g. 2.048(7) for $\mathrm{R}=$ 1-adamantyl [45] and 2.032(2) for $\mathrm{R}=\mathrm{CH}_{2} \mathrm{CH}_{2} \mathrm{COOH}$ [46], and with the distances of 2.0278(11) and 2.019(4), previously determined for two crystalline modifications of the same compound [47].

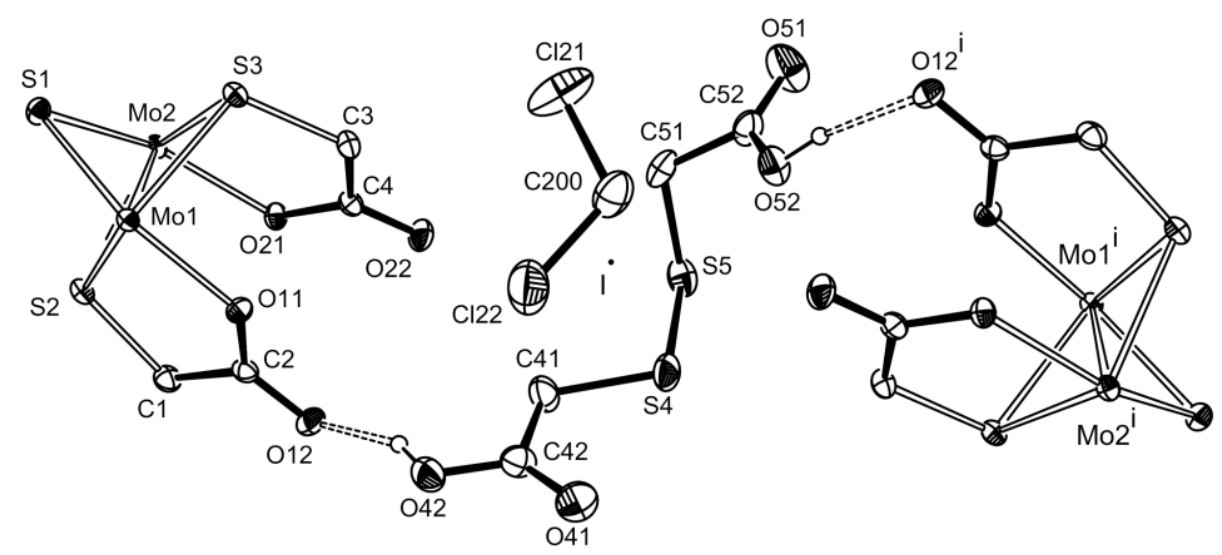

Figure 3. ORTEP diagram showing the hydrogen bonding network between $\mathrm{HOOCCH}_{2} \mathrm{~S}$ $\mathrm{SCH}_{2} \mathrm{COOH}$ and the dimolybdenum unit, and the disorder of the interstitial disulfide and dichloromethane molecules around the inversion center (shown). Only one of the two symmetry-related positions for each molecules is shown for clarity.

The disorder associated to the interstitial $\mathrm{CH}_{2} \mathrm{Cl}_{2}$ and $\mathrm{HOOCCH}_{2} \mathrm{SSCH}_{2} \mathrm{COOH}$ molecules is rather interesting. The diacid disulfide molecule is hydrogen bonded to the $\mathrm{O} 12$ atom of one dimolybdenum unit through one $\mathrm{COOH}$ function and to the same atom of another dimolybdenum unit through the second $\mathrm{COOH}$ function. The symmetry-related halfoccupancy molecule is hydrogen bonded to the same atoms. This means that only the $\mathrm{O} 12$ atom of the dimolybdenum fragment is engaged in hydrogen bonding, while the $\mathrm{O} 22$ atom is 
not. The hydrogen atom involved in this bonding was located from the Fourier difference map. It is located nearer the interstitial disulfide molecule $(\mathrm{O}-\mathrm{H}=0.85 \AA)$ and further from the bridging thioglycolate unit $(\mathrm{O} \cdots \mathrm{H}=1.75 \AA)$, confirming the nature of the dinuclear Mo complex as containing metal ions in the formal oxidation state IV. The intimate bonding parameters of the two independent carboxylate moieties (C2-O11-O12 on one side and C4O21-O22 on the other side) also reflect the hydrogen bonding interactions. The $\mathrm{C}-\mathrm{O}$ bonds involving the Mo-bonded oxygen atoms, namely $\mathrm{C} 2-\mathrm{O} 11$ and $\mathrm{C} 4-\mathrm{O} 21$, are longer than the corresponding ones involving the other oxygen atom, C2-O12 and C4-O22 (see Table 2), consistent with localized single and double bonds, respectively, for a molybdenum carboxylate unit. However, the C2-O12 bond, which is engaged in the hydrogen bond with the $\mathrm{O} 42$ proton, is slightly longer than the $\mathrm{C} 4-\mathrm{O} 22$ bond [1.233(3) vs. 1.217(3) $\AA$ ], which is not involved in hydrogen bonding. Conversely, C2-O11 is not as long as C4-O21 [1.289(3) vs. $1.310(3) \AA]$.

It is interesting to compare the reductive reaction leading to the title compound with the oxidative addition of the methyl ester of thioglycolic acid, $\mathrm{HSCH}_{2} \mathrm{COOCH}_{3}$, to $\mathrm{Cp}_{2} \mathrm{Mo}_{2}(\mathrm{CO})_{4}$ [48] (see Scheme 1). The two products are closely related to each other, because both are Sand thioglycolate-bridged dinuclear $\mathrm{CpMo}^{\mathrm{IV}}$ complexes. In the case of the oxidative process with the methyl ester in Scheme 1(a), the carboxylate functions are blocked by the $\mathrm{Me}$ substituents and do not coordinate the molybdenum center. The ideal replacement of the methyl groups with protons, followed by elimination of $\mathrm{H}_{2} \mathrm{~S}$, would lead to the product of the other reaction, Scheme 1(b). However, the two compounds have a totally different genesis, one deriving from an oxidative decarbonylation process (the presumed oxidizing agent being 
the SH protons, leading to $\mathrm{H}_{2}$ ), the other one being a reduction of a high oxidation state oxo compound. It may be predicted that a reaction of $\mathrm{Cp}_{2} \mathrm{Mo}_{2}(\mathrm{CO})_{4}$ with the thioglycolic acid could lead to the same product of Scheme 1(b), and that the reaction of $\mathrm{Cp}_{2} \mathrm{Mo}_{2} \mathrm{O}_{5}$ with the methyl ester of thioglycolic acid may lead to the same product of Scheme 1(a).

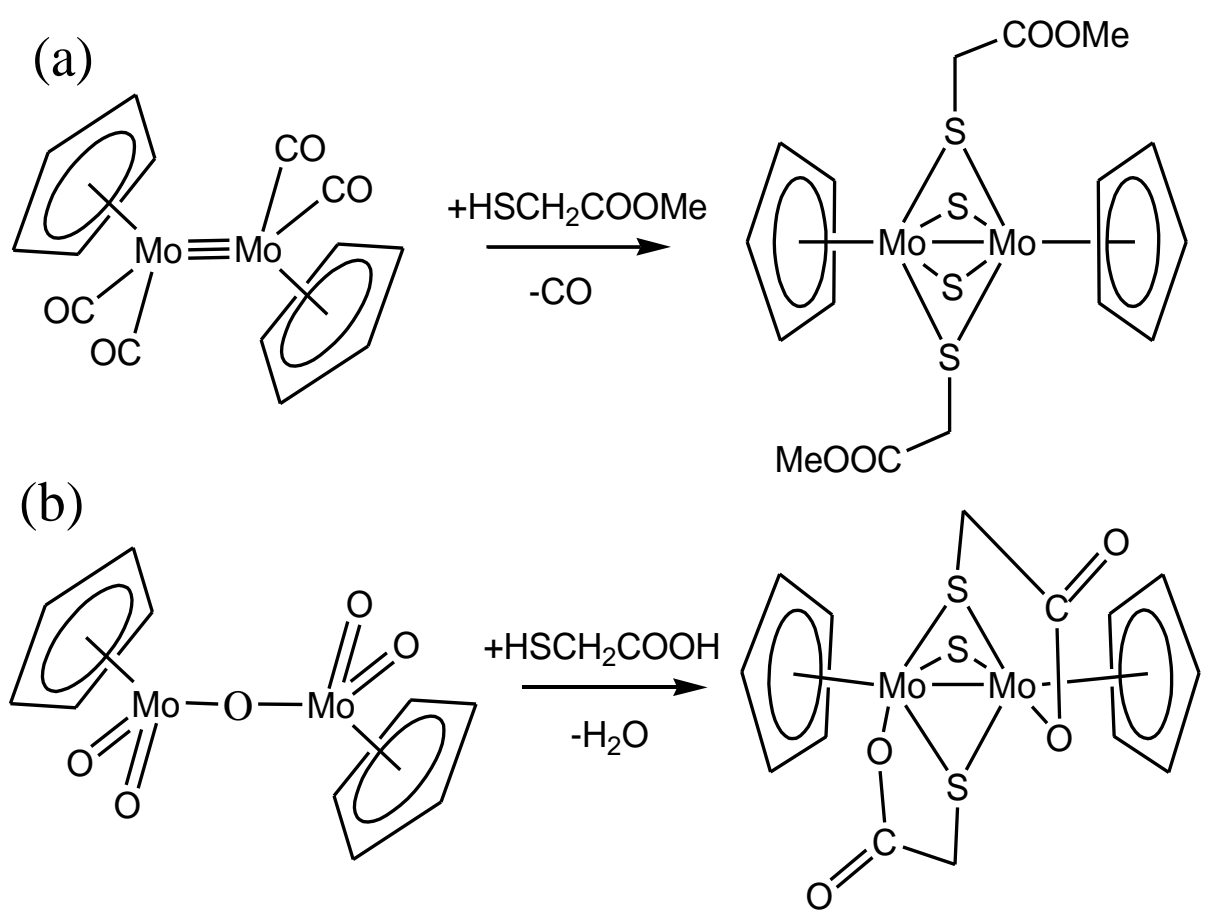

Scheme 1

\section{Conclusion}

We have shown in this paper that the interaction of $\left[\mathrm{Cp}^{*}{ }_{2} \mathrm{Mo}_{2} \mathrm{O}_{5}\right]$ with thioglycolic acid in a aqueous environment leads to a spontaneous reduction to $\mathrm{Mo}^{\mathrm{IV}}$, to the incorporation of the thioglycolate ligand, and to sulfide extraction. The reaction occurs quite readily at room 
temperature. It will now be interesting to test whether this reaction can be generalized to other sulfur compounds and whether the resulting products lead to any interesting stoichiometric or catalytic transformations.

\section{Acknowledgements}

This research was supported by the CNRS in France and by TUBITAK in Turkey. Supplemental travel support by a bilateral CNRS-TUBITAK (TBAG-U/62(102T211) program is also gratefully acknowledged. In addition, RP acknowledges support from the European Commission through the Research Training Network "AQUACHEM" (contract No. MRTN-CT-2003-503864) and the COST D29 program (working group 0009-03). FD thanks the University of Celal Bayar (FEF 2002/101, FEF 2005/023) for research grants.

\section{References}

[1] T. Chan, L. Li, Y. Yang, W. Lu, ACS Symp. Ser. 819 (2002) 166-177.

[2] F. Joó, Acc. Chem. Res. 35 (2002) 738-745.

[3] I. T. Horvath, Acc. Chem. Res. 35 (2002) 685.

[4] D. Sinou, Topics Curr. Chem. 206 (1999) 41-59.

[5] D. Sinou, Adv. Synth. Catal. 344 (2002) 221-237.

[6] G. E. Jaouen, J. Organomet. Chem. (special issue: bioorganometallic chemistry) 589 (1999).

[7] P. KalckF. Monteil, Adv. Organometal. Chem. 34 (1992) 219-284.

[8] B. E. Hanson, Coord. Chem. Rev. 186 (1999) 795-807.

[9] C. Muller, D. Vos, P. Jutzi, J. Organometal. Chem. 600 (2000) 127-143.

[10] W. A. Herrmann, E. Herdtweck, M. Flöel, J. Kulpe, U. Küsthardt, J. Okuda, Polyhedron 6 (1987) 1165-1182.

[11] W. A. Herrmann, Comments Inorg. Chem. 7 (1988) 73-107.

[12] R. Poli, Chem. Eur. J. 10 (2004) 332-341.

[13] E. Collange, J. Garcia, R. Poli, New J. Chem. 26 (2002) 1249-1256. 
[14] J. Gun, A. Modestov, O. Lev, D. Saurenz, M. A. Vorotyntsev, R. Poli, Eur. J. Inorg. Chem. (2003) 482-492.

[15] J. Gun, A. Modestov, O. Lev, R. Poli, Eur. J. Inorg. Chem. (2003) 2264-2272.

[16] E. Collange, L. Metteau, P. Richard, R. Poli, Polyhedron 23 (2004) 2605-2610.

[17] F. Demirhan, J. Gun, O. Lev, A. Modestov, R. Poli, P. Richard, J. Chem. Soc, Dalton Trans. (2002) 2109-2111.

[18] F. Demirhan, P. Richard, R. Poli, Inorg. Chim. Acta 347 (2003) 61-66.

[19] L. S. Meriwether, W. F. Marzluff, W. G. Hodgson, Nature (London, United Kingdom) 212 (1966) 465-467.

[20] J. F. MartinJ. T. Spence, J. Phys. Chem. 74 (1970) 3589-3596.

[21] L. Ma, S. Liu, H. Zhu, J. Zubieta, Polyhedron 8 (1989) 669-675.

[22] A. Cervilla, E. Llopis, J. A. Ramirez, A. Domenech, P. Palanca, M. T. Picher, C. A. Ghilardi, A. Orlandini, J. Chem. Soc., Dalton Trans. (1994) 175-183.

[23] W. B. Yang, C. Z. Lu, S. F. Lu, H. H. Zhuang, Helv. Chim. Acta 85 (2002) 24172429.

[24] D. Saurenz, F. Demirhan, P. Richard, R. Poli, H. Sitzmann, Eur. J. Inorg. Chem. (2002) 1415-1424.

[25] SDBS No. 10006HSP-02-695, National Institute of Advanced Industrial Science and Technology (AIST).

[26] A. Altomare, M. Burla, M. Camalli, G. Cascarano, C. Giacovazzo, A. Guagliardi, A. Moliterni, G. Polidori, R. Spagna, J. Appl. Cryst. 32 (1999) 115-119.

[27] G. M. Sheldrick, SHELXL97. Program for Crystal Structure refinement, University of Göttingen, Göttingen, Germany, 1997.

[28] L. J. Farrugia, J. Appl. Crystallogr. 32 (1997) 565.

[29] G. Charlot, Les Réactions chimiques en solution : l'analyse qualitative minérale., Masson et Cie, Paris, 1969.

[30] J. March, Advanced Organic Chemistry, Wiley, New York, 1992.

[31] M. Rakowski DuBois, R. C. Haltiwanger, D. J. Miller, G. Glatzmaier, J. Am. Chem. Soc. 101 (1979) 5245.

[32] M. McKenna, L. L. Wright, D. J. Miller, L. Tanner, R. C. Haltiwanger, M. Rakowski DuBois, J. Am. Chem. Soc. 105 (1983) 5329-5337.

[33] C. J. Casewit, R. C. Haltiwanger, J. Noordik, M. Rakowski DuBois, Organometallics 4 (1985) 119-129.

[34] J. C. V. Laurie, L. Duncan, R. C. Haltiwanger, R. T. Weberg, M. Rakowski DuBois, J. Am. Chem. Soc. 108 (1986) 6234-6241.

[35] R. T. Weberg, R. C. Haltiwanger, J. C. V. Laurie, M. Rakowski DuBois, J. Am. Chem. Soc. 108 (1986) 6242-6250.

[36] M. B. Gomes de Lima, J. E. Guerchais, R. Mercier, F. Y. Pétillon, Organometallics 5 (1986) 1952-1964.

[37] P. Grange, Catal. Rev., Sci. Eng. 21 (1980) 135-181.

[38] R. R. Chianelli, Catal. Rev., Sci. Eng. 26 (1984) 361-393.

[39] R. J. Angelici, Polyhedron 16 (1997) 3073-3088.

[40] C. BianchiniA. Meli, Acc. Chem. Res. 31 (1998) 109-116. 
[41] I. V. BabichJ. A. Moulijn, Fuel 82 (2003) 607-631.

[42] F. BottomleyJ. Chen, Organometallics 11 (1992) 3404-3411.

[43] F. Abugideiri, J. C. Fettinger, R. Poli, Inorg. Chim. Acta 229 (1995) 445-454.

[44] P. Schollhammer, F. Y. Pétillon, R. Pichon, S. Poder-Guillou, J. Talarmin, K. W. Muir, L. Manojlovic-Muir, Organometallics 14 (1995) 2277-2287.

[45] G. Rindorf, F. S. Joergensen, J. P. Snyder, J. Org. Chem. 45 (1980) 5343-5347.

[46] K. ProutS. Hernandez-Cassou, Acta Crystallographica, Section B: Structural Crystallography and Crystal Chemistry B38 (1982) 338-340.

[47] C. P. Nash, M. M. Olmstead, B. Weiss-Lopez, W. K. Musker, N. Ramasubbu, R. Parthasarathy, J. Am. Chem. Soc. 107 (1985) 7194-7195.

[48] W. Keim, Y. Zhu, E. Herdtweck, W. A. Herrmann, J. Mol. Catal. 58 (1990) 355-361. 
Table 1. Crystal data and refinement parameters for $\left[\mathrm{Cp}_{2}{ }_{2} \mathrm{Mo}_{2}\left(\mu-\mathrm{SCH}_{2} \mathrm{COO}\right)_{2}(\mu-\right.$ $\mathrm{S})] \cdot 1.5\left(\mathrm{CH}_{2} \mathrm{Cl}_{2}\right) \cdot 0.5\left(\mathrm{HOOCCH}_{2} \mathrm{SSCH}_{2} \mathrm{COOH}\right)$

Empirical formula

Formula weight

Temperature

Wavelength

Crystal system

Space group

Unit cell dimensions

Volume

$\mathrm{Z}$

Density (calculated)

Absorption coefficient

$\mathrm{F}(000)$

Crystal size

Theta range for data collection

Index ranges

Reflections collected

Independent reflections

Completeness to theta $=26.31^{\circ}$

Absorption correction

Max. and min. transmission

Refinement method

Data / restraints / parameters

Goodness-of-fit on $\mathrm{F}^{2}$

Final R indices [I $>2 \operatorname{sigma}(\mathrm{I})]$

$\mathrm{R}$ indices (all data)

Largest diff. peak and hole
$\mathrm{C}_{24} \mathrm{H}_{34} \mathrm{Mo}_{2} \mathrm{O}_{4} \mathrm{~S}_{3},\left(\mathrm{CH}_{2} \mathrm{Cl}_{2}\right)_{3 / 2},\left(\mathrm{C}_{4} \mathrm{H}_{6} \mathrm{O}_{4} \mathrm{~S}_{2}\right)_{1 / 2}$ 893.07

180(2) K

$0.71073 \AA$

Triclinic

$\mathrm{P}-1$

$\mathrm{a}=12.0469(11) \AA \quad \alpha=104.398(7)^{\circ}$.

$\mathrm{b}=12.4252(12) \AA \quad \beta=93.885(7)^{\circ}$.

$\mathrm{c}=13.7051(10) \AA \quad \gamma=115.745(9)^{\circ}$.

1753.1(3) $\AA^{3}$

4

$1.692 \mathrm{Mg} / \mathrm{m}^{3}$

$1.221 \mathrm{~mm}^{-1}$

904

$0.37 \times 0.34 \times 0.19 \mathrm{~mm}^{3}$

3.27 to $26.31^{\circ}$.

$-13<=\mathrm{h}<=15,-15<=\mathrm{k}<=14,-17<=\mathrm{l}<=17$

13162

$7136[\mathrm{R}(\mathrm{int})=0.0225]$

$99.7 \%$

Semi-empirical from equivalents

0.7236 and 0.6514

Full-matrix least-squares on $\mathrm{F}^{2}$

7136 / 0 / 454

1.055

$\mathrm{R} 1=0.0301, \mathrm{wR} 2=0.0743$

$\mathrm{R} 1=0.0375, \mathrm{wR} 2=0.0777$

0.934 and -0.704 e. $\AA^{-3}$ 
Table 2. Selected bond distances $(\AA)$ and angles $\left({ }^{\circ}\right)$ for $\left[\mathrm{Cp}_{2}{ }_{2} \mathrm{Mo}_{2}\left(\mu-\mathrm{SCH}_{2} \mathrm{COO}\right)_{2}(\mu-\right.$ $\mathrm{S})] \cdot 1.5\left(\mathrm{CH}_{2} \mathrm{Cl}_{2}\right) \cdot 0.5\left(\mathrm{HOOCCH}_{2} \mathrm{SSCH}_{2} \mathrm{COOH}\right)^{\mathrm{a}}$

\begin{tabular}{llll} 
& \multicolumn{1}{c}{$\operatorname{Mo}(1)-\mathrm{Mo}(2)$} & \multicolumn{1}{c}{$2.7929(4)$} & \\
$\operatorname{Mo}(1)-\mathrm{CNT}(1)$ & $2.0083(3)$ & $\operatorname{Mo}(2)-\mathrm{CNT}(2)$ & $2.0176(3)$ \\
$\operatorname{Mo}(1)-\mathrm{O}(11)$ & $2.0944(18)$ & $\mathrm{Mo}(2)-\mathrm{O}(21)$ & $2.0855(18)$ \\
$\operatorname{Mo}(1)-\mathrm{S}(1)$ & $2.3061(8)$ & $\mathrm{Mo}(2)-\mathrm{S}(1)$ & $2.3146(7)$ \\
$\operatorname{Mo}(1)-\mathrm{S}(2)$ & $2.4515(7)$ & $\mathrm{Mo}(2)-\mathrm{S}(2)$ & $2.4746(7)$ \\
$\operatorname{Mo}(1)-\mathrm{S}(3)$ & $2.4501(7)$ & $\mathrm{Mo}(2)-\mathrm{S}(3)$ & $2.4329(7)$ \\
$\mathrm{S}(2)-\mathrm{C}(1)$ & $1.824(3)$ & $\mathrm{S}(3)-\mathrm{C}(3)$ & $1.823(3)$ \\
$\mathrm{C}(1)-\mathrm{C}(2)$ & $1.521(4)$ & $\mathrm{C}(3)-\mathrm{C}(4)$ & $1.513(4)$ \\
$\mathrm{O}(11)-\mathrm{C}(2)$ & $1.289(3)$ & $\mathrm{O}(21)-\mathrm{C}(4)$ & $1.310(3)$ \\
$\mathrm{O}(12)-\mathrm{C}(2)$ & $1.233(3)$ & $\mathrm{O}(22)-\mathrm{C}(4)$ & $1.217(3)$ \\
$\mathrm{S}(4)-\mathrm{S}(5)$ & $2.026(4)$ & &
\end{tabular}

$\begin{array}{lclc}\text { CNT1-Mo(1)-S(1) } & 112.16(2) & \mathrm{CNT} 2-\mathrm{Mo}(2)-\mathrm{S}(1) & 111.55(2) \\ \text { CNT1-Mo(1)-S(2) } & 129.923(19) & \mathrm{CNT} 2-\mathrm{Mo}(2)-\mathrm{S}(2) & 124.689(19) \\ \text { CNT1-Mo(1)-S(3) } & 120.933(19) & \mathrm{CNT} 2-\mathrm{Mo}(2)-\mathrm{S}(3) & 126.28(2) \\ \text { CNT1-Mo(1)-O(11) } & 105.16(5) & \mathrm{CNT} 2-\mathrm{Mo}(2)-\mathrm{O}(21) & 105.77(5) \\ \text { CNT1-Mo(1)-Mo(2) } & 164.394(12) & \mathrm{CNT} 2-\mathrm{Mo}(2)-\mathrm{Mo}(1) & 164.201(12) \\ \mathrm{S}(1)-\mathrm{Mo}(1)-\mathrm{S}(3) & 75.37(3) & \mathrm{S}(1)-\mathrm{Mo}(2)-\mathrm{S}(3) & 75.55(2) \\ \mathrm{S}(1)-\mathrm{Mo}(1)-\mathrm{S}(2) & 75.76(3) & \mathrm{S}(1)-\mathrm{Mo}(2)-\mathrm{S}(2) & 75.16(3) \\ \mathrm{S}(3)-\mathrm{Mo}(1)-\mathrm{S}(2) & 109.01(2) & \mathrm{S}(3)-\mathrm{Mo}(2)-\mathrm{S}(2) & 108.81(2) \\ \mathrm{S}(1)-\mathrm{Mo}(1)-\mathrm{Mo}(2) & 52.951(19) & \mathrm{S}(1)-\mathrm{Mo}(2)-\mathrm{Mo}(1) & 52.675(19) \\ \mathrm{S}(3)-\mathrm{Mo}(1)-\mathrm{Mo}(2) & 54.825(17) & \mathrm{S}(3)-\mathrm{Mo}(2)-\mathrm{Mo}(1) & 55.403(17) \\ \mathrm{S}(2)-\mathrm{Mo}(1)-\mathrm{Mo}(2) & 55.854(18) & \mathrm{S}(2)-\mathrm{Mo}(2)-\mathrm{Mo}(1) & 55.071(17) \\ \mathrm{O}(11)-\mathrm{Mo}(1)-\mathrm{Mo}(2) & 89.99(5) & \mathrm{O}(21)-\mathrm{Mo}(2)-\mathrm{Mo}(1) & 90.04(5) \\ \mathrm{O}(11)-\mathrm{Mo}(1)-\mathrm{S}(1) & 142.64(5) & \mathrm{O}(21)-\mathrm{Mo}(2)-\mathrm{S}(1) & 142.46(5) \\ \mathrm{O}(11)-\mathrm{Mo}(1)-\mathrm{S}(2) & 79.17(5) & \mathrm{O}(21)-\mathrm{Mo}(2)-\mathrm{S}(2) & 87.34(5) \\ \mathrm{O}(11)-\mathrm{Mo}(1)-\mathrm{S}(3) & 87.35(5) & \mathrm{O}(21)-\mathrm{Mo}(2)-\mathrm{S}(3) & 79.29(5) \\ \mathrm{Mo}(1)-\mathrm{S}(1)-\mathrm{Mo}(2) & 74.37(2) & & \\ \mathrm{Mo}(1)-\mathrm{S}(2)-\mathrm{Mo}(2) & 69.07(2) & \mathrm{Mo}(2)-\mathrm{S}(3)-\mathrm{Mo}(1) & 69.77(2) \\ \mathrm{C}(2)-\mathrm{O}(11)-\mathrm{Mo}(1) & 127.77(17) & \mathrm{C}(4)-\mathrm{O}(21)-\mathrm{Mo}(2) & 127.22(17)\end{array}$




$\begin{array}{llll}\mathrm{C}(1)-\mathrm{S}(2)-\mathrm{Mo}(1) & 100.26(9) & \mathrm{C}(3)-\mathrm{S}(3)-\mathrm{Mo}(2) & 100.73(9) \\ \mathrm{C}(1)-\mathrm{S}(2)-\mathrm{Mo}(2) & 108.42(10) & \mathrm{C}(3)-\mathrm{S}(3)-\mathrm{Mo}(1) & 107.95(9) \\ \mathrm{C}(2)-\mathrm{C}(1)-\mathrm{S}(2) & 113.37(19) & \mathrm{C}(4)-\mathrm{C}(3)-\mathrm{S}(3) & 113.84(19) \\ \mathrm{O}(12)-\mathrm{C}(2)-\mathrm{O}(11) & 122.6(3) & \mathrm{O}(22)-\mathrm{C}(4)-\mathrm{O}(21) & 123.2(3) \\ \mathrm{O}(12)-\mathrm{C}(2)-\mathrm{C}(1) & 119.2(2) & \mathrm{O}(22)-\mathrm{C}(4)-\mathrm{C}(3) & 119.6(3) \\ \mathrm{O}(11)-\mathrm{C}(2)-\mathrm{C}(1) & 118.2(2) & \mathrm{O}(21)-\mathrm{C}(4)-\mathrm{C}(3) & 117.2(2)\end{array}$

${ }^{\mathrm{a}} \mathrm{CNT}(\mathrm{x})$ is the ring centroid of the pentamethylcyclopentadienyl ligand bonded to atom Mo(x). 